Vol. 5, No. 1, 2019

УДК 321.7

https://doi.org/10.23939/shv2019.01.036

\title{
QUANTIFICATION METHODS OF THE CHECKS AND BALANCES SYSTEM STUDY
}

\author{
Khrystyna Zabavska \\ Lviv Polytechnic National University \\ khrystyna.y.zabavska@lpnu.ua \\ ORCID: 0000-0002-4870-8230
}

(стаття надійшла до редколегї - 19.03.2019 р., стаття прийнята до друку-18.04.2019 р.)

(C) Забавська Х., 2019 .

The article deals with the main quantification methods of the system of checks and balances. Taking into account the main historical stages of the development of ideas concerning the functioning of the checks and balances system, on the basis of the comparative method, the main features of understanding the functioning of different aspects of checks and balances system by using mathematical methods are emphasized.

Having systematized mathematical techniques, the author of the article offers its own typology on the basis of highlighted criteria. The classification of quantification methods including methods of studying the level of presidentialism, methods to compare the powers of the president and parliament, methods related to the calculation of parliamentary powers, is proposed. The features and peculiarities of all these methods are critically considered in the article. Each quantification methods is analyzed in detail and special attention in the article is paid to the main the disadvantages of their use in the study of checks and balances system as a whole.

The article provides a description of the technics and formulas used in the application of each of methods. It is emphasized that a part of the methods are used to rank the states in the form of government, while another part is used to index and create a common list of states by this or that index accordingly. But all of these methods are focused on a specific component of the checks and balances system and are aimed at the sphere of the influence of a separate political player indexing. A comprehensive mathematical method for the system of checks and balances as a basic guarantee of democratic functioning needs to be proposed.

Key words: checks, balances, method, quantification methods, index, branches of power, cluster analysis, ranking, system, formula.

\section{КВАНТИФІКАЦЙНІ МЕТОДИКИ ДОСЛДЖЕННЯ СИСТЕМИ СТРИМУВАНЬ І ПРОТИВАГ}

\author{
Христина Забавська \\ Національний університет "Львівська політехніка" \\ khrystyna.y.zabavska@lpnu.ua \\ ORCID: 0000-0002-4870-8230
}

Розглянуто основні квантифікаційні методики дослідження системи стримувань і противаг. Враховуючи основні історичні етапи розвитку ідей щодо функціонування системи стримувань і противаг, основуючись на порівняльному методі, окреслено основні особливості розуміння функціонування окремих аспектів системи стримувань і противаг за допомогою використання математичних методів.

Запропоновано класифікацію методів кількісного дослідження, а також методики вивчення рівня президентської влади, порівняльні методики повноважень президента i парламенту, методики розрахунку парламентських повноважень. Усі характерні особливості застосування цих методик критично проаналізовано. Зміст кожної методики кількісного аналізу системи стримувань і противаг детально окреслено, а особливу увагу приділено основним недолікам їх використання під час вивчення системи стримувань і противаг загалом.

Ключові слова: стримування, противаги, методика, чисельні методи, індекс, гілки влади, кластерний аналіз, ранжування, система, формула. 
The application of mathematical methods in social sciences faces problems and criticisms from adherents of traditional methods of research in this area of cognition. Despite considerable discussions and critique of the practice of applying quantitative methods in political science, at the present stage of its development they are gaining popularity. In particular, the use of quantification methods for the study of certain elements of the system of checks and balances becomes rather popular.

In particular, we are talking about the methods of index and cluster analysis, which are used for a detailed study of the models institutional and functional organization of state power. The study of the use of quantification methods for the analysis of elements of the system of checks and balances is particularly topical for the implementation of comparative studies of the functional capacity of branches of power in the state, given the lack of statebuilding experience in Ukraine. The purpose of the article is to carry out an analysis of the quantification methods of studying checks and balances system elements.

Among the most prominent scholars involved in the use of mathematical techniques in researching elements of the checks and balances system were scholars such as Shugart, Carey, MacGregor, Metcalf, Krouwel, Zaznayev, Lokshyn and others. Among the Ukrainian scientists who were engaged in research on the use of cluster and index analysis in the study of elements of the checks and balances system are Seriogina, Romaniuk, Lytvyn, Lebedyuk, and others. At the same time, in the works of these and other scientists there is no systematization and comprehensive analysis of the mathematical methods used in the checks and balances system study. In addition, most of the existed methods focus on one side of the power pole: presidentialism or parliamentarism.

At present, the index of presidential authority of the in various forms of government has become the most widespread. The index analysis of the presidential power is the most widespread in Western political science and already involves about ten mathematical methods of measurement. This made it possible to significantly expand the possibilities of comparative analysis and to investigate the functioning of the presidential institution in various types of republican-democratic rule more thoroughly. We propose to singl out several groups of the existed quantification methods:

\section{Methods of studying the level of presidentialism:}

1) The presidential authority index by Shugart and Carey (1992), which is based on a simple interval method. The total numerical value of the president's powers is calculated on the basis of two groups: legislative and non-legislative powers. Each authority is evaluated on the basis of a differentiated system of grades for a 5-point system (where 0 is the president does not have these powers, and 4 is the president owns these powers in full force) [Shugart 1992].

The authors rank the political regimes in terms of presidential powers (for this they selected two variables from their list - "cabinet formation" and "cabinet resignation") and the degree of separation of sources of support for the assembly and cabinet, using variables "cabinet distrust" and "dissolution of the assembly". Their first criterion of typology is the power of the president (the degree of control) over the cabinet, the second - the separate survival of the assembly and cabinet. For the operationalization of the first criterion, the presidential power index over the cabinet is used, which is the sum of two indicators - "cabinet formation" and "cabinet resignation", and for the second criterion to be operationalized, the index of separate survival, which is the sum of indicators of "distrust of the cabinet" and "dissolution of the assembly" . Separate survival of the assembly and the cabinet indicates how the cabinet and the parliament depend on each other. If, at dissolution of the parliament, the cabinet continues to function, then such survival is maximal. Countries are placed in a matrix dictated by the authors, depending on the values of the indexes (See Table 1) [Shugart 1992].

Despite the significant strengths of this methodology, its main disadvantage is the limitation only to the assessment of formally approved and constitutionally prescribed powers.

2) Method of McGregor. The author, on the basis of the 43 presidential powers he has allocated, has created two indixes of the presidential power balanced and unbalanced. All the powers that the president owns, MacGregor assigns a numerical value - " 1 "; then laments all "units" in three categories: 1) symbolic, ceremonial and procedural powers, 2) powers relating to appointment, 3 ) political authority; the amount is calculated by " 0.5 " for each partial, limited or power that the president shares with someone; the percentage of the amount received from " 43 " is calculated - the maximum possible indicator. Because of its simplicity, McGregor's method has become widely known in western political theories. However, one should take into account - the main disadvantage is that all 
presidential powers are considered to be equivalent, without taking into account that such an analysis is rather one-sided and does not make it possible to differentiate the powers of the president because of their importance and influence on the political processes taking place in the state [McGregor 1994].

Typology of Democratic Regimes by Shugart and Carey

Table 1

\begin{tabular}{|l|l|}
\hline Max & \\
\hline Parliamentary-presidential & \\
\hline & \\
\hline Prime-presidential & Parliamentary \\
\hline None & \\
\hline
\end{tabular}

3) The method of Hellman. The author assigns each authority a number, depending on whether it belongs solely to the president, or is given to the president with restrictions, or not at all. In systems with a presidential form of government, the rating " 1 " is assigned with exclusive powers, " 0,5 " powers with reservations and rating " 0 " - those powers that are not given to the president at all. In parliamentary systems with direct presidential elections (apparently Hellman refers to semipresidential systems), grades are, respectively, set to: "0.75", " $0,35 "$ and "0". In parliamentary systems with indirect president elections, others are evaluated: " 0,5 ", " 0,25 " and " 0 ". Hellman substantiates the idea of the dependence of the size and importance of presidential powers on the form of government. Hellman's methodology is intended to calculate the presidential power index (based on the sum of indicators) and rank the countries from the largest to the smallest indexes [Хеллман 1996].

4) Frye's method. An American researcher uses the same list of presidential powers as Hellman. However, he divides them into two groups exclusive powers and shared authority ("shared"). If the president is elected by direct elections, the exclusive powers of the president are indicated by the number " 1 ", and the joint powers are " 0,5 ". If the president is not elected nationwide, then each of his powers is assigned a " 0,5 ". Then all numerical values are summed up [Frye 1997].

5) Index of presidential power by Norgaard and Johannsen. The IPA is calculated using coding for the three main groups of constitutional authority resources - symbolic, designated resources and political resources. If the president has a resource in full, unlimited form, then the number " 1 "; if its resource is limited - " 0,5 "; if he does not have such power - " 0 ". The IPA formula is:

$$
\begin{gathered}
I P A=(1(\Sigma S 1-7)+2(\Sigma A 1-13)+ \\
+3(\Sigma P 1-17)) x E x L=I S / 336 \times 100
\end{gathered}
$$

where IPA - index of presidential authority;

$S$ - symbolic resources (7 of them): the value of each is " 1 ", " 0.5 " or " 0 ";

$A$ - intended resources (13 of them): the value of each is " 1 ", " 0,5 " or " 0 ";

$P$ - political resources (17): the value of each is "1", "0,5” or " 0 ";

$E$ - mode of presidential elections: direct elections ("2"); parliamentary elections ("1");

$L-$ duration of the presidential term: limited term ("1"); the lifetime election of the president ("2"); 
IS - index value in relation to the maximum possible index (336), which is calculated using the same formula as:IPAmax $=((7 \times 1)+(2 \times 13)+(3 \times 17)) \times 2 \times$ $\times 2=336$

IPA is used by authors in prescribing typologies, analyzing correlations and regressions. In the latter two cases, the problem of the relationship between the form of government and other variables economic (GDP per capita and index of economic freedom) and political (freedom index) may be solved [Johannsen 2003].

II. Methods for comparing the powers of the president and parliament:

1) Index of the level of presidentialism Krouwel (LPrez). The Dutch scientist, in his calculations, analyzes powers within the two variables - the parliamentary index (IPar) and the presidentialism index (IPres). When encoding, the following numerical values are used: if IPres is calculated, then " 1 " is assigned a sign that is unambiguously associated with presidentialism, " 0 " - if this attribute can in no way be attributed to the presidential system. On the contrary, if IPar is calculated, then " 1 " is assigned a sign of parliamentarism, " 0 " - $\mathrm{f}$ the sign is not typical for parliamentarism. In cases of incomplete and general authority, " $0,5 "$ is used. For example, " 0,5 " is assigned when the president (for IPres) or parliament (for IPar) divides the powers of dissolution of parliament with another actor.

Krouwel puts numerical values in seven variables: 1) presidential election, 2) dissolution of parliament, 3) formation of the government, 4) parliamentary vote of confidence, 5) vote of no confidence, 6) the right of legislative initiative and the president's veto, 7) powers of the executive branches of power.

After defining IPres and IPar (each - by summing up the numerical data of variables), the level of presidentialism is calculated by the formula:

\section{IPres - IPar $=$ LPres}

Positive values (+) indicate presidentialism, negative (-) - parliamentarism [Krouwel 2003].

2) Index of form of government by Zaznayev. The Russian researcher made an attempt to improve the methodology of Krouwel and on its basis created a methodology aimed at determining the form of government of a particular state. Taking into account the changes made to Krouwel's methodology, Zaznayev identified the ten criteria for measuring the presidential power score (PresS) and parliamentary power. The maximum value of the indicator for each criterion is " 1 ", the minimum is " 0 ". As in the Krouwel's calculation, there is an intermediate variant - " 0,5 ". The maximum value for the presidential index (if any) and for the parliamentary index score (ParIS) is "10". By calculating the parliamentary index from the presidential index, you can get the Index of form of government (IFG):

\section{IFG $=$ PresS - ParIS}

The positive values of IFs indicate the attraction of the system to the presidential form, and the negative - to the parliamentary form. The greater the numerical value of the index, the more the system has presidential or parliamentary elements. The zero value of the IFG means the balance of power [Zaznaev 2014]

3) Lokshnyn Index of political rates. This method is aimed at determining the powers of the president and the upper and lower chambers of parliament. The author assumes that all significant powers are allocated by the constitution between the three authorities - the president, the upper and lower chambers of parliament. Taking all the set of powers that are allocated for 1 , one can write:

$$
w^{\text {pre }}+w^{l c h}+w^{u c h}=1,
$$

where $w^{\text {pre }}$ - the political weight of the president, $w^{l c h}$ - the political weight of the lower chamber of parliament, $w^{u c h}$ - the political weight of the upper chamber of parliament [Локшин 2013].

Another limitation is that the weight of each authority varies from 0 to 1 , including the limit values. The political weight of each actor in the body will be equal $\frac{w^{i}}{e n a_{i}}, e n a_{i}-$ effective number of actors in a political body of power $i$. Taking these assumptions into account, including the reciprocal relationship between the equivalence of authority distribution among institutional positions and the magnitude of political rates, the final version of the formula for calculating Index of the size of political rates (ISPR):

$$
I S P R=\sum_{j=1}^{n \mid i} \sum_{i=1}^{3}\left(w_{i_{j}}\right)^{2},
$$

where $i$ - one of the three authorities (to be accurate $i=1$ indicates president, $i=2-$ indicates the lower chamber of parliament, $i=3$ - indicates upper chamber of parliament), $j-$ an institutional position in the government, $n \mid i$ - number of institutional positions (or, what is the same, effective number of actors) depending on the authority $i$. But according to the above mentioned assumption, the weight of one institutional position is equal to the weight of the relevant authority divided by 
the effective number of actors [Локшин 2013]. Due to this, the formula is simplified to the next:

$$
I S P R=\sum_{i=1}^{3} e n a_{i} \times\left(\frac{w_{i}}{e n a_{i}}\right)^{2}=\sum_{i=1}^{3} \frac{\left(w^{i}\right)^{2}}{e n a_{i}}
$$

III. Methods related to the calculation of parliamentary powers:

1) Index of parliamentary powers by Fish and Kroenig. Today, this technique is the most successful and important attempt to measure the completeness of powers of the legislative body of a particular state in the framework of cross-national comparative research. To calculate the index, the authors allocated 32 parliamentary powers that cover the parliament's ability to exercise control over the president, parliamentary freedom from the presidential control, parliamentary powers in specific areas, and the level of bureaucracy. The more indicators are inherent in that or another parliament, the stronger it is. For each coincidence, the numerical value " 1 " is assigned, the numerical values are summed up and then divided into 32. The authors evaluate not only the formal powers of the parliament in the constitution, but also conduct a survey of at least five experts from each country, which also confirm or not confirm data on a particular indicator [Fish 2011].

2) Effective number of parties indexes. An effective number of parties points to the likely composition of the parliament and directly allows you to predict how consolidated the interaction of parties in it will be and how the majority and minority in the legislature will be formed and function. In political science there are two methods of calculating this index

- Effective number of parties (ENP) by Laasko and Taageper is calculated on the basis of determining the amount of support each party holds during the election. This indicator is quite significant for determining the party system in the state, which directly affects the definition of party competition within the parliament. This statistic is usually used to evaluate multiparty systems. The formula of Laakso and Taageper is:

$$
E N P=\frac{1}{\sum p_{i}^{2}}
$$

where $p_{i}$ - the percentage of votes received by the iparty in elections, or the percentage of deputy mandates received by the i-party in parliament [Laasko 1979].

- The index of the effective number of parties by G. Golosov (Np)

$$
N_{p}=\sum_{1}^{x} \frac{1}{1+\left(s_{1}^{2} \div s_{i}\right)-s_{i}}
$$

where $s_{1}$ - the proportion of parliamentary seats or votes of the party's voters who have gained the largest share of seats or votes, $s_{i}$ - the proportion of parliamentary seats or votes of the i-party voters. The value of the largest party is always equal to " 1 ", while the rest of the parties are calculated from the size of the largest party. Algorithm of calculation $\mathrm{Np}$ differs from ENP algorithm. To calculate the index, we first calculate $\frac{1}{1+\left(s_{1}^{2} \div s_{i}\right)-s_{i}}$ where $s_{1}-$ constant value for each variable $s_{i}$, and then add weighted numbers from each party [Golosov 2009].

This index better measures the effective number of batches in highly fragmented and least fragmented party systems, fulfilling the necessary properties for an index of this kind.

Among other methods that assess the party systems and key players in the political arena of the state should be called the index of proportionality of Gunter, the index of disproportionality of Gallagher, the index of fractalisation Raye, the index of uncertainty preferences electorate Pedersen [Шестак 2014].

Also, in thegame theory there is a large number of techniques that are aimed at studying the internal distribution of the influence of political players in the state. In particular, it is the Shepley-Shubik resolution party index (1954); Banzhaf Index (calculated by the fate of coalitions); The index of political influence of Deegan-Pakel etc.

In the late 1960s, Stephen Brahms made an interesting attempt to compile an index of concentration of power in political systems. But his methodology is directed at the study of actors, but not at their powers [Brams 1968].

From the abovementioned it follows that today in political science repeatedly attempts were made to apply a numerical index analysis of the branches of power authorities. However, for all of our considered and analyzed methods, there are certain disadvantages and weaknesses, among which:

1) unilateral consideration of powers through the prism of only one or two branches of government;

2) consideration of only legally approved and constitutionally authorized powers and failure to take into account the practical side of their implementation;

3 ) the lack of disclosure of the branches of power influence level of one on one; 
4) a non-diversified approach to assigning numerical values to separate powers of the branch of government;

5) lack of a unified approach to the ranking of states in the form of government;

6) the absence of a clear ranking of the results of the obtained indicators due to the calculation performed.

Bearing in mind the above-mentioned methods and defining their advantages and disadvantages, it should be noted that nowadays political science is open to active scientific research of optimal methods of mathematical adjustment of the system of checks and balances. We have systematized the existing methods of studying separate elements of the checks and balances system by offering the appropriate classification. Having outlined relevant groups of the existing mathematical methods within the framework of political science, we critically assessed the shortcomings and opportunities of each of them.

The above-mentioned shortcomings show the necessity for political science to take into account the need for a method that would be directed towards a comprehensive analysis of the system of checks and balances and quantification of its elements within the political system of a particular state. Today, in fact, there is no complex method of numerical study of the checks and balances system. In the direction of such studies, there are open wide opportunities for further scientific.

\section{ЛІТЕРАТУРА}

Лебедюк, В. (2013). Трансформація партійних систем у пострадянських країнах. Науковий часопис НПУ імені М. П. Драгоманова, Вип.: спец. вип., 222-229.

Локшин, И. (2013). Индекс величины политических ставок. Москва: Изд. дом Высшей школы экономики.

Романюк, А., Литвин, В. (2016). Порівняльний аналіз політичних інститутів країн Вишеградської групи та інших країн Центрально-Східної Свропи. Львів: ЛНУ ім. Івана Франка.

Серьогіна, С. (2008). Типологізація форм правління методами індексного та кластерного аналізу: сучасний стан і перспективи розвитку. Державне будівництво та місцеве самоврядування, Bun. 16, 3-15.

Хеллман, Дж. (1996). Конституции и экономическая реформа в переходный период. Конституционное право: восточноевропейское обозрение, № 2, 16-26.

Шестак, Н. (2014). Емпіричні методи дослідження політичних партій та партійних систем. Вісник Львівського університету. Серія філософсько-політологічні студії. Bun. 5, 144-155.

Brams, S. (1968). Measuring the Concentration of Power in Political Systems. The American Political Science Review, Vol. 62(2), 461-475.

Fish, S., Kroenig, M. (2011). The Handbook of National Legislatures: A Global Survey. Cambridge University Press.
Frye, T. (1997). A Politics of Institutional Choice: PostCommunist Presidencies. Comparative Political Studies, Vol. 30, 523-552.

Golosov, G. (2009). The Effective Number Of Parties: A New Approach. Party Politics, Vol. 10, 171-192.

Johannsen, L., Norgaard, O. (2003). IPA: The Index of Presidential Authority. Explorations into the Measurement and Impact of a Political Institution. Paper prepared for the ECPR Joint Sessions of Workshops, 24-27. New Orleans, LA.

Krouwel, A. (2003). Measuring presidentialism and parliamentarism: An Application to Central and East European Countries. Acta Politica, Vol. 38, 333-364.

Laasko, M., Taagepera, R. (1979). Effective Number of Parties: A Measure with Application to West Europe. Comparative Political Studies, Vol. 12, 3-27.

McGregor, J. (1994). The Presidency in East Central Europe. RL Research Report, Vol. 3, 12-16.

Metcalf, L. (2000). Measuring Presidential Power. Comparative Political Studies, Vol. 33(5), 660-685.

Shugart, M. S., Carey, J. M. (1992). Presidents and Assemblies. Constitutional Design and Electoral Dynamics. Cambridge University Press.

Siaroff, P. (2003). Comparative Presidencies: The Inadequacy of the Presidential, Semi-Presidential and Parliamentary Distinction. European Journal of Political Research, Vol. 42 (3), 287-312.

Zaznaev, O. (2014). Measuring Presidential Power: A Review of Contemporary Methods. Mediterranean Journal of Social Sciences, Vol. 5, 569-573.

\section{REFERENCES}

Brams, S. (1968). Measuring the Concentration of Power in Political Systems. The American Political Science Review, Vol. 62(2), 461-475.

Fish, S., Kroenig, M. (2011). The Handbook of National Legislatures: A Global Survey. Cambridge University Press.

Frye, T. (1997). A Politics of Institutional Choice: PostCommunist Presidencies. Comparative Political Studies, Vol. 30, 523-552

Golosov, G. (2009). The Effective Number Of Parties: A New Approach. Party Politics, Vol. 10, 171-192.

Hellman, J. (1996). The Constitution and Economic Reform during the Transition Period. [In Russian]. Constitutional Law: East European Review, Vol. 2, 16-26.

Johannsen, L., Norgaard O. (2003). IPA: The Index of Presidential Authority. Explorations into the Measurement and Impact of a Political Institution. Paper prepared for the ECPR Joint Sessions of Workshops, 24-27. New Orleans, LA.

Krouwel, A. (2003). Measuring presidentialism and parliamentarism: An Application to Central and East European Countries. Acta Politica, Vol. 38, 333-364.

Laasko, M., Taagepera, R. (1979). Effective Number of Parties: A Measure with Application to West Europe. Comparative Political Studies, Vol 12, 3-27.

Lebedyuk, V. (2013). The Transformation of Party Systems in Post-Soviet Countries. [In Ukrainian]. Scientific journal of Drahomanov NPU: Special Issue, 222-229. 
Lokshyn, I. (2013). The Index of the Size of Political Rates. [In Russian]. Moscow: House of the Higher School of Economics.

McGregor, J. (1994).The Presidency in East Central Europe. RL Research Report, Vol. 3, 12-16.

Metcalf, L. (2000). Measuring Presidential Power. Comparative Political Studies, Vol. 33(5), 660-685.

Seriohina, S. G. (2008). Typologization of Forms of Governance by Methods of Index and Cluster Analysis: the Current State and Prospects of Development. [In Ukrainian]. Public Construction and Local Government, Vol. 16, 3-15.

Shestak, N. (2014). Empirical Methods of Research of Political Parties and Party Systems. [In Ukrainian]. Visnyk of Lviv University. A series of philosophical and political studies, Vol. 5, 144-155.
Shugart, M. S., Carey, J. M. (1992). Presidents and Assemblies. Constitutional Design and Electoral Dynamics. Cambridge University Press.

Siaroff, P. (2003). Comparative Presidencies: The Inadequacy of the Presidential, Semi-Presidential and Parliamentary Distinction. European Journal of Political Research, Vol. 42 (3), 287-312.

Romanyuk, A., Lytvyn, V. (2016). Comparative Analysis of Political Institutions of the Countries of the Visegrad Group and Other Countries of Central and Eastern Europe. [In Ukrainian]. Lviv: Ivan Franko University of Lviv Publishing House.

Zaznaev, O. (2014). Measuring Presidential Power: A Review of Contemporary Methods. Mediterranean Journal of Social Sciences, Vol. 5, 569-573. 